\title{
Two Unpublished Letters About the Use of the Volgare sent to Alessandro Piccolomini
}

\author{
Rita Belladonna
}

Alessandro Piccolomini's volgarizzamenti, one of the pillars upon which his fame rested in the sixteenth century, have been largely ignored by comparison with his commentary to Aristotle's Poetics. Yet at the time when they were written, Piccolomini's vernacular translations marked a great step in the search for a linguistic medium which would apply not only to literature but also to philosophy and science, and which could be generally understood by an educated public throughout all Italy. ${ }^{1}$ His volgarizzamenti thus meant an extension in the functions of the vernacular to include the expression of scientific and philosophic thought. The resulting greater general accessibility to a sphere of knowledge which, until then, had been limited to those who had been trained in Latin and Greek did not fail to awaken adverse reactions in some quarters. The aim of this paper is to present two hitherto unpublished letters addressed to Piccolomini by two Sienese contemporaries, one of whom criticized his use of the vernacular for the diffusion of non-literary thought, whereas the other one expressed himself in Piccolomini's favour.

Before examining the two letters, it will be advisable briefly to review Piccolomini's linguistic position. On the whole, there has been a general tendency to ascribe his views regarding the use of the volgare almost exclusively to the presence of Sperone Speroni, to whose influence Piccolomini was exposed during his stay in Padua between 1538 and 1542. It is true that the Intronati, the literary academy to which Piccolomini belonged before his departure from Siena, even though it was devoted to the advancement of the vernacular, showed no sign of a systematic approach to the problem of producing Italian translations which would render nonliterary knowledge more accessible to its members. ${ }^{3}$ Yet when attributing Piccolomini's views on the vernacular exclusively to the influence of the Paduan environment, one tends to overlook the fact that Siena was also the home of a previous academy, the Senese or Grande, founded very early in the century, among whose members, until he was exiled in 1518 for political reasons, there was Claudio Tolomei, one of the greatest philologists QUADERNI d'italianistica Volume VIII, No. 1, 1987 
of his times. ${ }^{4}$ Thus even before Piccolomini reached intellectual maturity, discussions about the nature and function of the vernacular had been taking place in Siena, to some extent as a reaction to Giangiorgio Trissino's ill-fated attempt to reform the orthography of Italian. Tolomei's advanced linguistic views reflected the nature of the republican context in which they had originated. In that environment, in spite of the growing political instability, culture still related to the interests of a free dynamic mercantile bourgeoisie. There had been as yet no attempt on the part of an alien power, such as the Medici, to manipulate the Sienese intellectuals. ${ }^{6}$ The Accademia Grande probably remained in existence until as late as $15344^{7}$ thus coinciding with the foundation and early activities of the Intronati. Hence it may be useful to re-examine briefly some of Tolomei's basic ideas so as to gain a better understanding of Piccolomini's background.

On the whole Tolomei, like other Tuscan linguists, tends to obliterate the difference between the spoken and the written languages. ${ }^{8}$ As stated in Il Polito, a dialogue published by Tolomei in 1525 under the pseudonym of Adriano Franci, which probably depicts the sort of learned debate which took place among members of the Accademia Grande, writing is only the visible image of the spoken word. The latter in turn serves to express thought, which ultimately relates to facts. ${ }^{9}$ Language is thus defined as a convention regulated by usage, and it is viewed by Tolomei primarily as a tool for social communication. ${ }^{10}$ The communitarian territorial aspect of language is further emphasized in another dialogue, Il Cesano. A language should first of all be clearly understood by the person using it; next it should be understood by those with whom he shares a house, as well as by his neighbours and fellow-citizens. It would be good if it could also be understood by all the inhabitants of a province. Indeed, according to Tolomei the wider the area throughout which a language is understood, the better it is. Yet he is aware that nature has set geographic limits to linguistic expansion. ${ }^{11}$ Tolomei's unpublished Trattato della lingua toscana contains a detailed description of the average Tuscan language which he was trying to define. Tuscan consists of four layers of vocabulary. The first one, which includes ancient firmly-rooted words, and the second one, containing words originally introduced by learned speakers and subsequently accepted by everyone, are the basis of everyday language. The two remaining layers contain words exclusively used by writers, but not by the common people. ${ }^{12}$ Tolomei's linguistic ideas, which clearly stress communication within a well-defined community, relate to the comparatively free republican environment in which he spent most of his early life. As for other Tuscan linguists, also for Tolomei social communication is the primary purpose of language, with a noticeable slant towards stressing the 
importance of thought based on factual information as opposed to rhetorical ornament. Language is thus viewed as a flexible tool apt to express any content, be it literary or philosophical and scientific. ${ }^{13}$ The only limitation imposed upon the expansion of a language is a natural geographic one. ${ }^{14}$ The mystique of literary expression as the element that sets a writer and his creations for above the flux of time, a view held by Bembo among others, is completely ignored.

There can be no doubt that Alessandro Piccolomini absorbed these ideas in his formative years, since there must have been numerous opportunities for exchanging views among members, all belonging to the upper bourgeoisie, of two academies whose activities temporarily overlapped. It is probably safe to assume that before leaving for Padua in 1538, when he was thirty years old, Piccolomini must have been fully aware of the importance of everyday linguistic usage as a medium for social communication. In Padua he became acquainted with Pietro Pomponazzi's views on language as conveyed by his former student, Sperone Speroni, who was Piccolomini's friend and a fellow-member of the Accademia degli Infiammati.

In Speroni's Dialogo delle lingue Pomponazzi's linguistic views are presented as relating to his conception of a natural order governed by laws which, more Aristotelico, can be apprehended through sense experience. ${ }^{15}$ In Pomponazzi's universal scheme language is nothing but an arbitrary creation of man for practical purposes. ${ }^{16}$ Hence one man's language is as valid as that of another man; whether or not a subject is expressed in a certain language is entirely a matter of convention. ${ }^{17}$ Nature, which undergoes no mutations, may be studied by any man at any time with the tool of any language. ${ }^{18}$ Since language is thus just a means for the achievement of knowledge, human beings must be allowed to use whatever medium of expression is natural to them. ${ }^{19}$ Thus one's vernacular language, unencumbered by rhetorical ornament, is to be preferred to Greek or Latin. Words are merely accidental; they are not magic glass vessels containing a philosopher's genie. ${ }^{20}$ Though Pomponazzi was an Aristotelian, his linguistic ideas probably relate to the Platonic distinction between res and verba. ${ }^{21}$ Only res matter to the philosopher, whose ultimate aim is the pursuit of knowledge which can be expressed through any linguistic medium.

It is probably safe to assume that Pomponazzi's idea as conveyed by Speroni must have rendered Piccolomini further aware of the importance of the vernacular not only as it related to a cultural and geographic area, as it did in Tolomei's thought, but as a means to serve the ideal pursuit of philosophic knowledge by all men. As a result of his exposure to two such major linguistic influences, Piccolomini soon conceived his grand 
plan of translating some key philosophic works into the Tuscan language. His primary aim was that of rendering the sources of education available to readers who had no knowledge of Latin and Greek. Yet his purpose extended far beyond that. Whereas Pomponazzi was utterly indifferent to the language in which philosophy and science were expressed, Piccolomini basically wished to replace Latin and Greek by the use of the vernacular. Thus he shows concern for the creation of a compact Italian culture, regulated not by geographic considerations but by the broader concept of language as the means to develop the human mind. His initial attitude as the defender of the Tuscan vernacular, which he shared with Tolomei, thus evolved beyond the barriers of provincialism into a universalism which certainly owed much to Pomponazzi, but which nonetheless showed a feeling for the creation of a national Italian culture which Peretto, in his utter philosophic indifference, never experienced. ${ }^{22}$ Moreover, there is also an implicit revolt against the tyranny of classical languages in Piccolomini's thought. No doubt this was partly derived from Pomponazzi, but it was also part and parcel of the somewhat iconoclastic vernacular-oriented tendency current in the cultural academies to which Piccolomini belonged all his life. ${ }^{23}$ His views are nowhere more clearly expressed than in his educational treatise, entitled De la institutione di tutta la vita de l' huomo nato nobile $e$ in città libera, which was first published in 1542. The passage remained almost totally unchanged in the second version of the same work, published in 1560 . When addressing the problem of the texts required to impart a solid education to a well-born child, Piccolomini deplores the fact that his imaginary student should have to spend many years learning Latin and Greek in order to study science and philosophy.

He goes on to express the hope that enough Italian translations will soon be available to free children from such a sad necessity. ${ }^{24}$ Yet, when all is said, it would be naive to consider Piccolomini's translations as an attempt to "democratize" culture. ${ }^{25}$ His volgarizzamenti were initially addressed to his fellow-members of literary academies and, subsequently, to the literate public at large. In his prefaces Piccolomini often stresses the point that his use of the volgare as opposed to Latin and Greek cannot render the contents of a work any clearer. ${ }^{26}$ No nowledge of style and rhetoric will give its possessor access to philosophic or scientific truth. A reader equipped with rhetorical knowledge can at most belong to what Piccolomini contemptuously calls "la plebe dei letterati." His translations are addressed to a vernacular-educated bourgeois elite, certainly a wider public than that addressed by classical humanists, but which certainly did not include the lower classes. ${ }^{27}$ The fact that some of Toloniei's ideas became incorporated in Piccolomini's works caused them to survive the political 
decline of the environment in which they had originated. With the fall of Siena in Cosimo de'Medici's hands in 1555 , there was a marked return to authority. ${ }^{28}$ Cosimo evolved a cultural policy which enabled him to foster any trends conducive to his own political prestige. ${ }^{29}$ In this policy there was no room for the independent activity of academies; they had to be placed under the guidance of the authorities. ${ }^{30}$ Obviously, the safest linguistic trend from Cosimo's viewpoint could only be the one represented by a non-Tuscan, Pietro Bembo, who fulfilled the double aim of enhancing the nobility of ancient Tuscan while at the same time he pressured intellectuals into expressing themselves in a language other than modern Tuscan. The latter might be deemed too close to republicanism to be totally safe from Cosimo's point of view.

Let us now look at the two letters addressed to Piccolomini. The author of the first one, written from Siena probably ln 1541, when Piccolomini was studying at Padua University, was Federico Orlandini, another member of the Accademia degli Intronati. ${ }^{31}$ The letter, written in Latin, ${ }^{32}$ expresses strong disapproval of Piccolomini's plan to translate Aristotle, Alexander of Aphrodisias, Simplicius, Ammonius and others into Italian. Reviewing the attitude towards knowledge current in classical antiquity, Orlandini reaches the conclusion that philosophy should never be revealed to the ignorant masses. His examples include Pythagoras, who left no writings but instead conveyed his esoteric knowledge to his own daughter only verbally, Plato, who used Socrates as a persona so as to avoid writing in the first person, and Aristotle. Philosophic writings ought to be expressed in obscure terms so as not to be understood by the common crowd. In the second part of his letter, Orlandini describes a parallel tendency in the Old and the New Testaments. Moses was enjoined by God not to reveal all that had been disclosed to him. Also Christ admonished His disciples not to cast pearls before swine. To conclude, Orlandini states that Piccolomini's translations will be of no use to anyone: the learned will always prefer to read the original texts, whereas the unlearned will continue to be unable to grasp the hidden meaning of philosophy, even after the linguistic barrier has been removed. Orlandini's remarks are largely based on ideas which had already been expressed by Giovanni Pico della Mirandola. The allusions to Moses and to Pythagoras, for instance, derive from Pico's Oratio. ${ }^{33}$ Curiously enough, it is from Pico's letter to Ermolao Barbaro that Orlandini derives his most important arguments against the volgare, that is, that the language of philosophy and religion should be deliberately obscure and that knowledge should not be made accessible to all. ${ }^{34}$ Yet Orlandini distorts Pico's meaning to suit the aims of his own polemic against Piccolomini. Pico had polemized with Barbaro against 
humanistic rhetoric, in favour of the mode of expression of scholastic philosophy, even if the latter entailed a certain degree of obscurity. Pico was thus reacting against the empty artifice which he perceived in humanistic style. ${ }^{35}$ Thus in many respects Pico's attitude towards language as a tool for the pursuit of knowledge was very close to the attitude latter adopted by Pomponazzi ${ }^{36}$ Orlandini appropriated Pico's arguments against Latin rhetorical style and used them in his wholesale condemnation of the use of the vernacular to express philosophic subjects. In doing so, he used Pico's remarks, transferring them to the sphere of the vernacular, to express the linguistic conflict between two sharply differentiated cultural classes, the minority who were placed in a position of superiority by the fact that they knew Latin and Greek and the majority who were considered culturally inferior because of their ignorance of those languages.

Piccolomini must have taken Orlandini's critique to heart. Nine years later he confuted most of Orlandini's remarks in his dedication to Pope Julius III of the first part of his natural philosophy. ${ }^{37}$ Claiming for himself the merit of being the first one ever to have systematically dealt with philosophic subjects in the vernacular, Piccolomini mentions those who enviously oppose the diffusion of knowledge. After remarking that the use of classical languages does not in the least denote the possession of a great mind, ${ }^{38}$ Piccolomini explains that the transmission of knowledge has undergone three stages. In the first one, which has sometimes been called the Golden Age but which, in reality, was a period when men were rough and inexperienced, philosophic knowledge had to be expressed in allegorical poetical form in order to protect it from being defiled by the ignorant. The second stage was represented by Pythagoras and his use of numerical symbols. The third stage was that of the Peripatetics, who cast all symbols aside and devoted themselves to the pursuit of truth based on fact. Thus the need to clothe knowledge in a symbolic garb has now disappeared. Piccolomini also reaffirms his national educational purpose, alluding to the many gentili ingegni che sono in Italia who will derive a benefit from his work. Retorting against an assumption made by Orlandini in his letter, Piccolomini warns that the use of the vernacular will not in itself render the subject-matter of a work any easier to understand. ${ }^{39}$

Some of these arguments in favour of the vernacular, together with some other objections raised by the volgo dei letterati reappear in a letter addressed to Piccolomini by Marcantonio Piccolomini, one of the founders of the Accademia degli Intronati, among whom he was known as Il Sodo. ${ }^{40}$ The letter was written from Padua on October 20, 1551 and sent to Rome, where Alessandro was probably still in the service of Cardinal Francisco de Mendoza. Marcantonio Piccolomini records the reactions of some uniden- 
tified Paduan intellectuals to Alessandro's Prima parte de la filosofia naturale, published in 1551 together with the Instrumento de la filosofia. These works have been generally praised for their solid Peripatetic contents. Most readers are astonished by the clearness with which Alessandro has explained obscure points, particularly considering that he is the first to express a dottrina continuata in the vernacular. When referring to the linguistic aspect of Alessandro's works, Marcantonio reports that his style has been criticized by some who think that the rhythm of Alessandro's prose is too rapid and, conversely, by others who think that it is too slow. In such a confusion of discordant opinions, Marcantonio thinks that it is best to be content with the approval of judicious readers, which Alessandro certainly has. The constant preoccupation to recapture the numerus of Tuscan prose thus reappears in this letter. Marcantonio concludes that there is no point in worrying too much about it, considering that neither Aristotle nor Cicero or Quintilian where able to define the rules regulating the rhythm of classical prose. Some readers have criticized Alessandro's use of words which do not appear in Boccaccio's or Petrarch's works, as well as his use of neologisms. Marcantonio justifies Alessandro by resorting to arguments relating to the concept of language as a living human creation (Faithfull 278-82). Words become obsolete; even Boccaccio himself would have written in a different way had he lived in the sixteenth century. The use of neologisms is justified when an author is struggling to express something which has never been said before in a certain language. Cicero himself was compelled to use neologisms in Latin. Criticism of Alessandro's orthography and punctuation is considered ridiculous when referred to a language which has not yet reached full maturity. Marcantonio finds it hard to believe that some people should fail to understand the advantages, especially for the young, of having access to philosophy and science in the vernacular. he pours scorn on those who affirm that knowledge should not be rendered accessible to all. Once more Marcantonio expresses the idea of language as a mere vehicle for the transmission of knowledge. Thus a translation cannot by itself render the contents of any work at all easier. Marcantonio Piccolomini's letter confirms that the resistance against the use of the vernacular for non-literary subjects, which we observed in the previous letter, continued. His arguments in favour of the volgare appear mainly to derive from Alessandro Piccolomini himself, whom Marcantonio must have known for a long time.

Let us draw some conclusions. Wishing to pursue his educational ideals, Piccolomini broke the barriers which linked the Tuscan volgare to a limited geographic area and projected the language into universal realm of pure philosophic thought. In this way some of Tolomei's ideas survived after the 
gradual subjection by the Medici of the free republican Sienese bourgeoisie in whose midst such ideas had originated. Paradoxically, Piccolomini's innovative linguistic thought was coupled with great political conservatism, in that he was a faithful follower of the Medici (Celse 7-79). Because his linguistic views were so advanced, Piccolomini could not but feel contempt for those who limited themselves to the imitation of Petrarch and Boccaccio. His attitude in this respect relates him to the beginnings of the growing polemic against the ancients in favour of the moderns. ${ }^{41}$ Above all, it was Piccolomini's clearness as an interpreter of the classics that appealed to his contemporaries in an age in which rationality and lucidity were valued by most readers.

\section{York University}

\section{NOTES}

I The concept of a language common to all Italy had already been developing for some decades. See Grayson 144: "Nessun dubbio che quel periodo segni. . . la nascita del concetto di una lingua comune a tutta Italia." The period alluded to is, roughly, the first quarter of the sixteenth century.

2 Cerreta 36: "Al periodo padovano, e non ad un'altra successiva epoca della vita dobbiamo rifarci per trovare i germi del programma di volgarizzamento del Piccolomini."

3 De Gaetano 29: "The same is true of the two Sienese institutions which preceded the Florentine, the Intronati (1525) and the Rozzi (1551), for neither of these groups had conceived a comprehensive program for the vulgarization of all aspects of knowledge." The tendency to translate prose works is explained by Carlo Dionisotti 142: ". . . la moda delle traduzioni si inquadra in una società letteraria che, pur restando fedele all'incanto della poesia, cercava nella prosa un'espressione đi sé piú varia e pronta e continua. ... La nuova lingua non soltanto aveva aperto a molti, che prima ne erano esclusi, la possibilità di un onorevole e fruttuoso esercizio letterario: aveva anche in parte superato le barriere regionali della vecchia Italia, riproducendo e allargando lo sviluppo unitario della cultura umanistica."

4 For Claudio Tolomei see Sbaragli, and Weiss 35: "It was left to Claudio Tolomei to vindicate for the first time the excellence of the Siena vernacular, and prove the century's most original thinker in language matters." For the Accademia Grande vide Belladonna 229-48, and Kosuta, "L'Academie." The following remarks on the foundation of the Accademia Senese appear in the latter article 135-36: "Sur les origines de l'Académie siennoise, ses fondateurs et ses premières activités, nous ne possédons aucune informaton précise. Celle qui remonte le plus loin dans son passé est le dialogue du Polito, où des discussion philologiques sont signalées vers 1512 entre ses membres."

5 The dialogue entitled Il Polito was written to confute Trissino's attempt to reform the Italian alphabet; it was based on discussions which had actually taken place among members of the Accademia Grande; see Sbaragli $15 \mathrm{ff}$. 
6 For the manipulation of intellectuals on the part of the various governments, see Rochon 63-112, and also the following remark by Garin 68: "La cultura è componente essenziale della politica."

7 Loduys 135; for evidence of the foundation of the Intronati around 1525, see Petracchi Costantini 12.

8 Mazzacurati 124: "Particolarmente notevole, da parte del Tolomei, e l'anticipazione del concetto di uso popolare come fondamento e norma della lingua parlata e letteraria (anche per lui, come per tutti i toscani, non c'era gran differenza tra i due termini)."

9 Adriano Franci [Claudio Tolomei] pp. unnumbered: "Cosi dunque la scrittura è imagine de le parole, le parole de concetti, i concetti de le cose."

10 Hall, Jr. 35: "Tolomei and others also considered the prime purpose of language to be that of social intercourse."

11 Tolomei, Il Cesano 43-44: “. . . et quanto piu questa una lingua istender si potesse, meglio certo et piu utile al mondo sarebbe: ma non l'ha fatto, ne lo sostiene la grandezza della natura, et è avenuto, che una piu lunghi ha posti i termini suoi, l'altra piu corti. ..."

12 Tolomei, Trattato, quoted in Belladonna 239-40.

13 Tolomei, Il Cesano 76.

14 Tolomee, Il Cesano 54: "Finalmente non par che questo Idioma molto apprezzare si debbia per non haver i maestri di quello, cioe i Toscani, molto grande imperio, anzi poco et ristretto. ..."

15 Douglas 171: "Pomponazzi, like Aristotle, put unquestioning confidence in senseexperience," and 270: "Pomponazzi had formed a distinct idea of an order of natureof nature as a system, governed by pervading and uniform principles."

16 Sperone Speroni $122 \mathrm{v}$ : “. . . essendo fatte [language] et regolate dallo artificio delle persone a beneplacito loro. . . ."

17 Sperone Speroni 123r: “... perche il mondo non ha in costume di parlar di philosophia senon greco o latino; gia crediamo che far non possa altramente. . . ."

18 Sperone Speroni 125r: "Natura in ogni età, in ogni provincia, et in ogni habito esser sempremai una cosa medesima: laquale . . . cosi da ricchi parimente, et poveri huomini, da nobili, et vili persone con ogni lingua, greca, latina, hebrea, et lombarda, degna d'essere conosciuta, et lodata."

19 Sperone Speroni $125 \mathrm{r}$ “. . . quella lingua, et quella scrittura doversi usare da mortali, laquale con piu agio apprendono. ...."

20 Sperone Speroni 126r: “. . . non altramente, che se lo spirito d'Aristotele, a guisa di folletto in cristallo, stesse rinchiuso nell'alphabeto di Grecia. . . ."

21 Dionisotti 125, remarks as follows on the lingustic implications of Neoplatonism as they appear in Landino's introduction to his volgarizzamento of Pliny: "In termini di dottrina letteraria, il processo inevitabilmente si risolveva in una subordinazione delle parole alle cose, e pertanto delle lingue come di strumenti accidentali e intermutabili della conoscenza, alla conoscenza stessa, una e comune, quali che fossero le lingue usate per conseguirla."

22 See Garin, Medioevo e Rinascimento 141-42 for the difference between Pomponazzi's quest for pure knowledge and Piccolomini's educational aims: “. . . il bisogno di tener presente il linguaggio di tutti, traversa ed anima . . . le opere del Piccolomini . . . quanto il Piccolomini sia lontano dalla posizione del Peretto si vede, non solo in questa sua effettiva esigenza di volgarizzare per educare-e il riferimento alle donne 
e caratteristico-ma anche nel dichiarato proposito, non di tradurre Aristotele, ma di esporre una filosofia italiana. ..."

23 Dionisotti 194: "Alla rarefazione dei testi classici corrisponde il prodigioso moltiplicarsi dei volgarizzamenti. Era in parte una appropriazione spiccia e senza scrupoli, in parte anche una sfida, promossa dalla presunzione che la nuova lingua potesse in verso e in prosa competere con le antiche. ... Nel fondo ... urgeva un'ansia di modernità, di liberazione e di rivalsa sull'antico."

24 A. Piccolomini, De la institutione II.8.39v : "Ma spero bene (se Dio a tanta impresa non è contrario) che tosto, al men ne l'eta che è per seguire a la nostra, si troveran ne la nostra lingua al meno il fiore di quegli scrittori, che doppo l'incendio, e somersione d'infiniti libri, pur'oggi in pregio rimasti ne sono. E a l'hora non è dubio, che potendo gli huomini, i lor primi anni, tolti da l'apprendere de le lingue, a le scienze donare, vedrassi per la bella Toscana, de i Theofrasti, de gli Aristoteli, e de i Platoni." The same passage appears in III.9 of the second edition.

25 Scrivano, "Alessandro Piccolomini" 72: "Non si può pretendere naturalmente che in pieno Cinquecento il Piccolomini potesse arrivare a formulare un programma di educazione delle masse, ma va detto che il suo democratismo, privato di quella spinta che animava il pensiero pomponazziano, s'iscriveva in limiti ben precisi."

26 See A. Piccolomini, La prima parte 1: "Veggendo essi che nelle materie difficilissime, come son queste, se ben può uno recar loro maggior chiarezza, et con maggiore evidentia esplicarle, che un'altro non farà; tuttavia non è possibile che da chi si voglia si dia loro quella agevolezza, che non può ricever la lor natura. . . ."

27 Petronio, "La crisi italiana" 222-24.

28 Albertini 293: "Una componente essenziale di tutta la mentalità dell'epoca è il fondamentale bisogno di essere guidati da autorità."

29 Caponetto 41: "Cosimo, dopo la vittoria di Montemurlo sui fuorusciti, iniziò una politica culturale ridando prestigio allo Studio di Firenze con la chiamata nel ' 38 del grande umanista Pier Vettori . . . riorganizzando l'Universitaàa di Pisa, trasformando l'Accademia degli Umidi in un organismo statale."

30 The Intronati were denounced for heresy to the Inquisition in 1558. Alessandro Piccolomini, who was not personally suspected, was Prince of the Academy at the time. See Marchetti 155-56 and Pirri 118.

31 Federico Orlandini was born in Siena in 1515. He graduated in medicine in 1542 and became a professor at Siena University. He was on friendly terms with Aonio Paleario and, probably as a consequence of that, he was charged with heresy in 1542 . He was a member of the Intronati, his academic name being Il Dubbioso. His letter forms part of the collection bearing the title Federici Rolandini, seu Orlandini, Lucae Contilis et aliorum epistolae, MS H.IX.46, Biblioteca Comunale of Siena. See Kosuta, "Aonio Paleario" 32-35 and Note 216.

32 See Appendix I for the text of the letter.

33 Giovanni Pico della Mirandola-Gian Francesco Pico, Opera 1: 328-29: "Scribunt non modo celebres Hebraeorum doctores, sed ex nostris quoque Hesdras, Heilarius et Origenes, Mosen non legem modo, quam quinque exaratam libris posteris reliquit, sed secretiorem quoque et veram legis enarrationem in monte divinitus accepisse, praeceptum autem a Deo ut legem quidem populo publicaret, legis interpretationem nec traderet literis, nec invulgaret .... Pithagoras nihil scripsit nisi paucula quaedam, Quae Damae filiae moriens commendavit." 
34 Breen 397: "For the many we have not written, but for you and your likes. We are not unlike the ancients who by their riddles and by the masks of their fables made uninitiates shun the mysteries; and we have been wont by fright to drive them from our feasts, which they could not but pollute with their even more repulsive make-up of words."

35 Garin, Giovanni Pico della Mirandola 23: "In Pico risponde il filosofo che, per tanta parte riallacciandosi alla migliore ereditada medioevale, con Savonarola si scaglieraàa contro il mondo, ormai sempre piú vuoto ed astratto, degli umanisti."

36 The similarity is mentioned by Grayson 22: "It is a topic [language] which finds the Paduan Aristotelian Pomponazzi in some agreement with the Neoplatonist Pico della Mirandola. ..."

37 A. Piccolomini, "Al Beatissimo Padre." The dedication is dated April 1550.

38 A. Piccolomini, "Al Beatissimo Padre" pp. unnumbered: "Io posso veramente affirmare di cognoscere hoggi molti securi et spiditi ne la lingua Greca, et molti altri ne la Latina, et non pochi ne l'Hebrea, li quali non di meno poveri di scientie, rozi di buon costumi, et quasi stolidi d'intelletto, si fan conoscere."

39 A. Piccolomini, "Al Beatissimo Padre": "Non vorrei già per questo, che i Lettori si pensassero d'haver à leggerle, come si leggan Historie, ò novelle; talmente che aprendo il Libro, dovunque s'abbattin leggendo, credino di poeter senza avvertenza alcuna gustar le cose che vi sono."

40 See Appendix II for the text of the letter. Marcantonio Piccolomini was born in Siena in 1504 and died in Rome in 1579. He had been ordained nine years before. His name appears as one of the contributors to a collection of poems in memory of Giovan Battista Bogini, a Sienese friend of Aonio Paleario, whose name also appears in the collection; Caponetto 20. Marcantonio Piccolomini is the protagonist of Girolamo Bargagli's Dialogo.

41 A. Piccolomini, De la Institutione II.9.44r: "Appartiensi parimente à la compositione, che gli Epitheti non sieno di soverchio, ò vero improprij, ò molto spessi, ò gonfiati: come adiviene $\partial$ molti che non essendo Toscani si pensan di parlar Toscanamente, quando i Periodi loro (come ben se ne ride il divin Pietro Aretino) di Sollazevoli, di stellegianti e d'altre cosi fatte parole mescolate trà quinci, e quanchi, riempiano." The theme of the superiority of the moderns, already present in the first version of this work, is developed at great length in the second version of the Institutione, first published in Venice in 1560. 
APPENDIX I

MS H. IX. 46, Biblioteca Comunale of Siena

Federici Rolandini, seu Orlandini, Lucae Contilis et aliorum epistolas - Fra gli Intronati il Dubbioso.

$\left[109^{\mathrm{V}}\right]$ Fed. Orl. Alexandro Piccolomineo. sal.

Superioribus diebus cum ego Thomas Palmerius et Thadeus Montherculensis viri quidem ingenio doctrinaque praestantes, tum utrique nostrorum pro veteri benevolentia atque necessitudine coniunctissimi quadam in Bibliotheca librorum quorundam emendorum gratia $\left[110^{\mathrm{T}}\right]$ essemus, inter excutiendum (ut fit) in Alexandrum tuum Aphrodisiensem, quem nuper summa tua cum laude latinitate donaras, casu forteque incidimus. Cuius Titulo vel inscriptione maximopere invitati suaviterque allecti, epistolam inprimis, qua opus tuum Francisco Bandineo Piccolomineo Archiepiscopo nostro, quem tu propter eius summum ingenium, suavissimos mores, singularemque probitatem, plurimi sane facis, iure ac merito nuncupes, per quantum avide legere coepimus. Tandem eo devenimus ubi Aristotelem, Alexandrum, Simplicium, Ammonium denique caeterosque graecos eius interpraetes preclarissimos patrio sermone perbrevi locuturos polliceris et spondes. Quod unum, Alexander doctissime, cum aures meas (ingenue fateor) tum plurimum offendisset fereque a legendo absterruisset, operae praecium me facturum confestim existimavi si rationibus paritier et exemplis nonnullis animum tuum ab huiusmodi provincia laboreque ac penitus amoverem non odio, vel tui reprehendendi cupiditate adductus, quem admirari possunt omnes, reprehendere vero tam pauci quantum nemo imitari, sed amore quo te ducemque nostrorum Aristotelem complector. Quamobrem (ut hinc sermo noster ordiatur) Antiquos in Dei Naturaeque abditis obtegendis occultandisve omne studium, omnemque animi conatum semper adhibuisse, me $\left[110^{\mathrm{v}}\right]$ moriae proditum est. Quam legem observarunt ex ludis Brachmanae, Ethiopes, Persae, et Egiptij. Hinc horum splendor ac decus. Mercurius aiebat tractatum tota numinis maiestate plenissimum irreligiosae mentis est multorum consciae in apertum referre. Hoc Orpheus et vates omnes antiqui, hoc Pythagoras, qui vel nihil scripsit, vel siquid scripsit id Damae filiae moriens commendavit, monuitque ut secretum custodiret. Quod illa quamvis mulier diligentissime servavit, quamquam prae grandi pecunia vendere opusculum potuisset, noluit. Ferunt hoc ipsum Damam quoque postea morientem Vitaliae filiae suae mandasse. Hoc Socrates, Plato, Aristoxenus, Ammonius inviolabili fide servavere. Hinc Herennius, Plotinus, et Origenes (ut scribit 
Porphirius in de educatione et disciplina Plotini) iurarunt ne Ammonij dogmata ederent. Et quia Plotinus violato iureiurando ab Ammonio Praestito sacramenta in lucem protulit, in tansgressionis poenam (ut nonnulli asserunt) horrendo pediculorum edulio consumptus est. Est etiam nobis non mediocri argumento Lysidis epistola qua ad Hipparchum scribens arguit eum quod praecepta quaedam Pythagorae tradidisset atque alijs edidisset monetque bona philosophia cum ijs communicanda non esse qui ne animj quidem purificationem somniare $\left[111^{\mathrm{r}}\right]$ poteurunt neque fas esse ea omnibus porrigere quae nos tot laboribus atque vigilijs adepti suus quemadmodum nec profanis hominibus Eleusinarj ... [damaged text] licet arcana patefacere. Quod Plato quoque hoc ipsum semper diligentissime custodierit, latissime patet: neque enim libris, sed voce docuit nec de ijs quae docuerat libros reliquit. Si quid scripsit Socratis esse non suum fatetur. Ita praeterea de divinis rebus breviter, implicite atque obscure praecepta tradidit ut non facile a legentibus possit intelligi. Quod ipse quoque testatur in Epistola quam de natura primi entis ad Dionysium scripsit. "Scribendum est," inquit, "per ambages atque aenigmata, ut si forte mari vel terra iactari librum contigerit, qui legerit non intelligat." Mox autem, quasi eum paeniteret aliquid de ijs etiam per aenigma scripsisse, addit: "Hanc epistolam cum primum perlegeris, ures." Gloriatur etiam peripateticorum Dux se Alexandro (Themistio referente) ea lege sua naturalia instituta tradidisse, ut nemo intelligeret nisi ipse qui tradidit interpraetante. Primo etia de prima philosophia libro Egyptios sumptibus publicis sacerdotes aluisse, ut mathematicis caeterisque disciplinis vacarent, liquido testatur. Quod quidem si aequa lance metiri ac perpendere voluerimus, nil aliud hercle significare dicemus, nisi quod a Cerdonibus caeterisque infimae sortis humilisque for $\left[111^{\mathrm{v}}\right]$ tunae hominibus tam sublimes, tam altas disciplinas neque capessendas, nec attingendas ullo pacto putarent. At obijcies sacerdotes iccirco Mathematicis apud Antiquos operam navasse, non quod ij tantum rerum altissimarum cognitione atque scientia digni haberentur, verum quod a Rei domesticae cura atque Reipublicae administratione quam longissime alieni, expeditiores, aptioresve ad omnium optimarum artium doctrina animum excolendum existerent. Num et plerique alij curis negocijsque vacui, potuissent reperiri? Sed externis omissis summus rerum omnium opifex Deus (ut in veteri Testamento me pluries lectitasse memini) dum eius populus serviret in Egypto allocutus est Mosim et adduxit eum super Montem Sinai et detinuit eum apud se diebus multis et enarravit ei mirabilia multa et ostendit ei temporum secreta et fines, et praecepit ei dicens: "Haec in palam facies verba et haec abscondes." In palam enim fecit legis praecepta, Christi genealogiam, aliquas brevissimas priscorum patrum historias recluso tamen earum Sacramento. Item sacrifi- 
cia, caerimonias, Arcae fabricam, bellum cum Amalechitis et cum caeteris diversarum nationum Regibus. $\left[112^{\mathrm{r}}\right.$ ] Et hanc sapientiores haebrei legem scriptam appellant, in qua sublimiora sensa continentur atque multi exeogitant, quorum sensuum notitiam huiusmodi sapientes legem dicunt ore ad os. Quam iuxta praeceptum Domini viventis reservavit Moses ore septuaginta senioribus quorum successio duravit usque ad captivitatem factam a Nabucdonoxor, quo tempore cessavit aut diminuta fuit usque ad Cyrum. Tunc enim (divino suggerente spiritu) assignatis vasis templi quinque millibus quadringentis solutaque captivitate et remissis familijs ad numerum quadraginta duorum millium trecentorum et septuaginta, exceptis servis et ancillis, sub manu Zorobabel, Namiae et Exrae, reaedificari ceptum est Templum Domini. Quo resarcito et instauratis sacris (iubente Domino) doctrinam illam in septuaginta volumina iuxta numerum seniorum redegit ne dispergeretur. Nam: "Prima," inquit, "quae scripsisti, Textum scilicet Legis, in palam pones; legant digni et indigni. Novissimos autem septuaginta libros conservabis ut tradas eos sapientibus de populo tuo. In his enim est vena intellectus, sapientiae fons, et scientiae flumen, quae divino et inexcogitabili artificio sunt occlusa sub cortice." Summus omnium doctor et redemptor $\left[112^{\mathrm{v}}\right]$ Iesus filius Dei (ut ad recentiora sermo convertatur noster) discipulos docuit ne darent sanctum canibus neve margaritas ante porcos proijcerent conculcandas. Quae magistri monumenta ut servarent discipuli aut non scripserunt, aut quae solum ad miracula, mores componendos et legis instituta pertinent, ab omnibus observanda tradiderunt. Sic fecerunt Apostoli et Evangelistae omnes, Paulo et Ioanne excepto. Nam his tribus evangelijs iam vulgatis multisque exactis annis ad extirpandam heresim Ebionitarum, qui Christum hominem, sed non Deum asseverabant, de aeterna filij Dei generatione deque per ipsum hominis unione cum Deo mortificato primo animali nostro aliqua paucis et obscure pronunciavit. Apocalypsis mysteria tot involuit aenigmatibus ut nec Oedipus, qui solus sphingis nec Salomon, qui Sabae Reginae aenigmata solvebat, nec quispiam alius enodaret nisi eo spiritu perfusus, quo plenus erat ille qui scripsit. Altissima igitur profundissimaque, Dei Naturaeque mysteria uno omnium ore vulgo tradenda non sunt. Quoniam vero epistulae modum iampridem excessi, eam hac una ratiuncula concludam: vel tuus $\left[113^{\mathrm{r}}\right]$ est labor, suavissime Alexander, eruditis hominibus rofuerit, vel omnino literarum expertibus, doctis non. Et enim philosophum ipsum multo sane libentius graeco vel Romano idiomate loquentem audient quam Hetrusco. $\mathrm{Nec}$ ignaris, quandoquidem verborum tantum cortice praelibata, profundissima sensa pertingere nequibunt. Cum igitur cassa, irrita, atque inanis ista tua provincia omnium antiquorum Testimonio, ac denique ratione ipsa appareat, to rogo atque oro eam omnino animo tuo pellas, longissimeque 
reijcias. Hoc enim cum summae tibi laudi, tum Aristoteli ipsi iucundissimum gratissimumque futurum confido. Vale evi nostri decus ac me (quod equidem te facere semper arbitror) dilige. Senis Idibus Decemb. [1541]

\section{APPENDIX II}

MS C.IV.25, Misc. Benvoglienti, Biblioteca Comunale of Siena. Alcune notizie delle lettere di Marcantonio Piccolomini

\section{A M Alessandro Piccolomini a Roma.}

35. si come io non ho fin qui perduto ch'io sappia occasione alcuna di scrivervi com'io vivo sanissimo del corpo et sodisfattissimo dell'animo per la quieta et honorata stanza che è in questa Città cosi non voglio al presente lassare di dirvi come una bella schiera di dotti huomini molestano di continuo domandandomi quando habbino à venire in luce l'altre parti che restano de la vostra Filosofia. Et perche io ho saputo per lettere prima di M Anibale Lothorenghi e di poi men' a certificato a bocca M Giov. Batt.a Piccolomini vostro fratello quando fù qua, che voi eravate assai sollevato da la vostra lunga infermità, et che eravate molto risoluto alla primavera uscire di Roma et ridurvi per tutta la state in Toscana ala vostra villa di Valdasso per godervi la benignità de quell'aere che tante volte v'ha fatto diventar sano io ho dato loro da qualche giorno in quà buona speranza. Hora se questo vostro pensiero vi riesce si come io desidero et spero voglio ancor credere per cosa certa non sapendo voi vivere senza $i$ vostri studij pur un momento che tosto questa vostra impresa de la filosofia sia per havere quel successo che comunemente si spera; perche io non dubito che la sanità del corpo et la quiete dell'animo che trovarete in quella vostra villa ne la quale voi state cosi volontieri vi riscalderanno il desiderio à seguire l'impresa da voi incominciata; ove la vostra poca sanità et l'inquietudine di Roma vi hanno fin quà raffredato cosi bel pensiero; et io sò molto bene che infiniti si dogliono di questa vostra [17] indispositione; cosi per il danno che ne viene à voi come anche perche non posson godere $\mathrm{i}$ frutti del vostro ingegno nel modo che ne goderebbero se voi viveste sano et contento come desiderano. Et io per quel che àme ne tocca vi confesso che infinitamente mi doglio di questa vostra disgratia; perche considero che dal giorno che per consiglio d'altri, et fuori d'ogni vostra inclinatione voi vi privaste de la libertà et quiete vostra, sempre ò tanto o quanto vi ho veduto et di corpo poco sano et d'animo manco sereno; ove io pure mi ricordo et n'ho molti testimonij che da qualche anno adietro voi tra $\mathrm{i}$ vostri studi et vostri amici amatissimo et honoratissimo da ognuno facevate in Siena una vita riposata allegra, honorata et lodata tanto cosi 
da $\mathrm{i}$ nostri come anche da $\mathrm{i}$ forestieri che io non conoscevo persona di spirito et d'honore che non vi portasse invidia. Ma voglio ritornare à quello che per hora $m$ 'ha spinto à scrivervi principalmente. Dico che grandemente mi piace che siate per ridurvi in Valdasso per qualche mese; donde vi prego che alle volte vi pigliate fatica di scrivermi; cosi dell'esser vostro come anche di quello che io possa promettere de le vostre opere à tanti gentili spiriti che son quà et che l'aspettono di giorno in giorno. E poiche io son certo che io non vi posso esser sospetto d'adulatione non voglio restar di dirvi come tra questi studiosi ingegni di queste bande sono stati letti volontieri et tenuti in molta stima la prima parte de la vostra Filosofia, et il suo instrumento che mandaste fuora la vernata passata; lodasi la dottrina che vi si vede et è giudicata per legittima peripatetica. Tiensi per maravigliosa la chiarezza che havete à cose per natura loro cosi oscure, et maggiormen[18]te in una lingua nuova ne la quale voi siete il primo che l'habbia posta con dottrina continuata. Et se poi si trova qualch'uno che ò per sua maligna natura o per ignorantia ardisca di riprendervi ne le cosestesse; subbito da ogni parte se le rivolgono incontra huomini dotti che li fanno tacere con vergogna loro di modo che quanto appartiene ala dottrina non si trova hormai alcuno che ardisca di dare macchia à cosa che vi si legga. Vi dirò bene che quanto a la lengua trovo che de vostri scritti non son mancati dei caluniatori; perche primieramente intorno al numero, et intorno al suono che nasce da la compositione de le parole alcuni hanno giudicato che corga troppo piu risonante, et che sdruccioli con piu velocita al fine de le clausole et dei periodi di quel che si converrebbe; e per il contrario altri hanno detto che pare che ne vada interrotto talmente che chi legge può ad ogni passo agevolmente trovare inciampo. Tuttavia non è che molti non affermino che questo numero ò voliam dir suono dele parole composte sia con temperamento à bastanza convenevole, soave limpido et risonante. Et di questo mi pare che sia assai buono argomento che quelli che lo riprendono s'appoggiono a due vitij estremi; che è pur chiarissimo inditio che si debbia riporre ne la lodevole mediocrità di ciascun di questi due. Oltra di questo io considero che si come non si può trovar concento ò armonia alcuna di musica cosí soave ò armoniosa che non si trovino ancora orecchie a le quali non sodisfaccia, cosi ancora dico che non è da maravigliarsi che non si possa ò parlare o scrivere cosi numerosamente che non rimanga offeso il parere di qualch'uno. Tanto son varij i gusti et i giuditij [19] de gli huomini. Voglio per questo inferire $\mathrm{M}$ Alessandro mio, che à voi deve bastare assai, poi che e impossibile che lo stile dei vostri scritti sodisfaccia à tutti ugualmente et compiutamente, che à quelli almeno non dispiaccia che sono et di piu giuditio et di piu ingegno de gli altri; et à questi trovo veramente che non dispiace; 
e tanto maggiormente vi dovete contentare di questo intorno al numero de la oratione, quanto che non potendo ristrignersi cosi agevolmente sotto certa regola et ferma norma è forza che finalmente si venga accomodando all'orecchie de gli altri; le quali gia habbiam' detto che diversissime sono nell'apprenderlo et giudicarlo; et che non si possa regolare ordinatamente ne fanno ottimo testimonio Aristotile, M. Tullio, Quintiliano et molt'altri, i quali non hanno potuto ne darne regola ne trattarne compiutamente. Sono stati ancora oltra questi alcuni altri cosi schifi nelo scegliere de le parole, che non vogliono accettar per buona ne la lingua nostra parola alcuna che il Petrarca e'l Boccaccio non habbia usata; et si ristringon' sempre à certe tavole inutili et à certe vane osservationi quali s'hanno procacciate con infinita fatica facendo una continua anatomia di questi due scrittori che non ardiscono d'uscirne fuori un passo. Questi ch'io dico perche hanno trovato ne vostri scritti alcuni vocaboli che forse non si trovano in quei loro rimarj ò repertorij, s'adiron con voi et vene biasimono. Ben vi dico che questa calunnia è stata leggiera et che ogni di si fà piu debole; perche questi calunniatori son conosciuti di poco giuditio, et trovono di continuo chi gli [20] contrasta per difensione de la verità et vertu con ragioni et auctorità; et è mostrato loro chiaramente chel uso commune del parlare e il vero padre delle parole; et che come à padre non gli deve esser tolto il poter ogni giorno generare de le nuove secondo il bisogno; cosi per ristorare il danno per quelle che son morte et che muoiono tutto dí, come ancora per desegnare et dichiarare quei concetti di cose che prima non s'hebbero. Imperoche essendo le parole, e si come son veramente note et segni dell'intentione de gli huomini et finalmente delle cose istesse, chi dubita che concependosi alcuna cosa di nuovo, mentre che et nuove arti si ritrovono et le gia trovate s'accrescono et abbelliscono, non faccia di mestieri che similmente venghin fuora parole che non siano piu usate mai? Nessuno ch'io creda neghera che le parole che sono nel Boccaccio, gia tempo fù che non erano al mondo. et pure nacque di nuovo poi; ne si deve dubitare che s'egli ritornasse tra noi et volessi scrivere o parlare ne la sua lingua d'Astrologia, di filosofia naturale o d'altra facultà, usarebbe hoggi parole che non haverebbe usato prima perche non n'haveva bisogno. Cicerone stesso grandissimo apprezzatore della lingua latina alcuna volta, come voi ben sapete esprimere qualche concetto che non si poteva con parole usate fino al suo tempo; Onde gli bisogno fabricar nuovi vocaboli per farsi intendere; e ben vero che per fare questo avvertiva à due cose; la prima era che nel crear' nuove parole, pigliassele egli da la lingua greca ò pure altronde, le formava in tal modo [21] che si potessero talmente adattare con le latine, che si conoscessero per meno forestiere che fusse possibile; la seconda cosa che si procurava, era 
che ò vero produceva con tal giuditio i nuovi vocaboli che per loro stessi fussero intesi i loro significati, se si poteva fare; o vero non si potendo li dichiarava, la prima volta circonscrivendoli et soleva protestare sempre che fussero nuovi, le quali avvertentie tutte, si vede chiaro che voi ancora nel formare di nuovo quei vocaboli che v'è stato possibile, havete inviolabilmente et diligentemente osservato; talche coloro che di buono intelletto sono et che considerano tutto questo ch'io dico non solo non vi biasimano et da chi vi biasima vi difendono, ma vi lodano ancora; rallegrandosi che cosi felicemente cominci à spargersi la lingua nostra per molti più larghi et fruttuosi campi che non ha fatto per fino ad hora, mentre che drieto à novelle, a sonetti et à favole ha caminato. Non voglio oltra à queste cose lassar di dire alcune parole ancora dell'ortografia; intorno a la quale se ben non manca chi à pieno non si satisfaccia degli ultimi vostri libri che sono in luce, non havete per questo in tutto ne da maravigliarvi ne da dolervi poi che, sia chi si voglia, può molto bene conoscere che di questo possono in gran parte essere incolpati li stampatori et i loro correttori; il che piu notabilmente conosceranno quelli che hanno nel proprio originale veduti et letti li scritti vostri; Oltra che per non esser questa nostra lingua salita per ancora a quel grado di perfettione al quale spero che debbia tosto salire, non pare che tra i curiosi osservatori di quella sia fin ad hora cosi ben determinato tutto quello che ai punti, à le virgule, a le terminationi de i verbi, al tor' [22] via alcune lettere et ad altre cosi fatte politezze s'appartenga di considerare. Ma quello che sopra ogn'altra cosa mi pare in un medesimo tempo ridicolo et maraviglioso che huomini di cosi poco discorso ardischino di far professione di lettere, si è che non si può adattarsi ne gli animi di molti che giovamento possa essere lo scrivere in questa lingua italiana cose di Filosofia come fate voi; perciò che si fanno forti sopra d'uno argomento loro divisivo; dicendo ch'ai dotti questa impresa sara inutile poiche non n'hanno bisogno; et che à quei che non sanno, manco può recare giovamento, perche se bene le scientie sono scritte volgarmente et essi per questo non posson' senza maestro apprenderle in alcun modo. Et questa vana opinione ha talmente fermato le șue vive radici ne la mente loro ostinata, che per infinite ragioni con le quali ad ogni hora gli huomini letterati si sono ingegnati di svellerla non hanno potuto pure muoverla ò darli crollo. A questi tali io giudico che si convenga havere con passione, poiche accecati dall'ignoranza non comprendono che chi pone le scientie ne la lingua nostra non ha la mira sua indirizzata principalmente à questo che gli huomini gia d'anni maturi ò dotti ò non dotti e che sieno possino da quelle trarne una grande utilità, ma si bene accio che quelli che di poco tempo son' nati in questa bella provincia ò che vi hanno da nascere possino trovando le scientie ne la lingua materna loro darsi à quelle in- 
teramente senza havere à spendere i loro migliori anni nell'imparare ò la greca ò la latina ò qual si voglia altra lingua forestiera; Et cosi in breve per conseguentia arrivar tant'oltre ne la cognition de le cose, che se ben' haveranno bisogno di maestro nondimeno di assai gran fatica saranno liberi nell'apprender lingue straniere non haveranno da consumare il tempo. Queste ragioni et altre che voi molto bene havete raccolte in quella Epistola nuncupatoria che è posta al principio [23] della prima parte de la vostra naturale filosofia in luogo di proemio universale non son' capaci d'intender' questi huomini rozi d'intelletto. Un' altra ragione oltre queste che non lassano essere inutili queste vostre fatiche ne fù allogata ancora pochi di sono in Venetia ne la libreria del Tramazzino ove fù uno che molto arrogantemente affermava il poco giovamento di questa vostra impresa; e quasi stimando che quivi non potesse esser, alcuno che sapessi nulla, apriva la bocca senza punto considerare che sorte di parole n'uscissero; et tra alcuni litterati che v'erano et di lui si ridevono, uno ve ne fù il quale confessava apertamente, che da $\mathrm{i}$ vostri libri haveva guadagnato alcune dichiarationi et determinationi di materie di che ne gli altri interpreti d'Aristotile non haveva trovato mai ò Greci ò Latini che fussero; et affermava di non si curare da che sorte di lingua cavasse la chiarezza e vera notizia delle cose, pur' che l'acquistare quelle gli succedesse si come da i vostri scritti diceva che conosce maravigliosamente seguirgliene. Io adunque poi che tanti huomini di valore ne le lettere si fanno cosi beffe de le debolissime ragioni di costoro che parlono à caso dicendo esser cosa inutile il vostro donar' le scientie à la nostra lingua, piu dico che con molto ragione et con animo constantissimo debbiate seguire l'impresa vostra et maggiormente poi che questi ignoranti che cosi stridono sono à punto di quegli huomini che voi per dispregio solete chiamare volgo di litterati, a i quali sarebbe tanto meglio il non saper nulla che saper' cosi poco che solo gli basti per farli arroganti, quanto che quelli che sono ignoranti meramente non pensando di sapere, son privi di questa doppia et crassa ignorantia che in questi miseri si ritrova. Di questa medesima cecità et rozeza sono alcuni altri che giudicono da biasimare che vulgarmente si scriva et si tratti le cose di Filosofia solo perche cosi vengono à farsi troppo note del vulgo troppo comuni; cosa al parere loro fuor di ragione et non approvata da [24] Platone ne da altri filosofi; Et à me fù detto che in Roma à la tavola d'un gran prelato fù domandato da persone letterate ad uno che affermava questa stravagante opinione per verissima; s'egli haveva letto quel che voi per dichiaratione di questo dubio havevate scritto nel proemio universale de la vostra Filosofia Italiana; a che egli rispose che non; onde da tutta quella bella compagnia gli fù con scorno et con riso detto che molto mal faceva à riprendere et giudicare li scritti d'altrui se non li leggeva prima et considerava molto bene; 
percio che quando li havesse letti haverebbe conosciuto che la chiarezza e l'oscurità che siteneva ne le cose che si scrivono non ha da nascere da le lingue principalmente, ne le quali si scrivono ma si bene si trova et si pone ne le cose istesse et nel modo di scriverle, et ditrattarle; Et à provare questo allegarono l'esempio d'Orfeo, di Museo, di Pittagora, di Platone, et di altri antichi, i quali havendo scritto oscuramente forse per non far' commune al volgo gioiacosi pregiata come questa de le scientie non cercarono d'oscurar le cose con le lingue forestiere; ma ne le propie loro ponendole s'ingegnorono d'adombrare con il velame de le favole, de le translationi et d'altri figurati et colorati modi di dire. E veramente e pur cosa da ridere che queste cicale et questi ignoranti si persuadino che ogni volgar persona possa intender tutto quello che ne la sua propria lingua ritrovi scritto; come se la natura non havesse posto in altro la profondità delle cose sue più segrete che ne le lingue, di modo che ogni cosa (et sia quanto si volga per sua natura oscura et difficile) la quale si scriva con lingua volgare, s'havvia à intendere con quella agevolezza leggendola che se fusse qualche favola fanciullesca ò qualche novella.

Hora io vi confesso che troppo mi son' raggirato d'attorno à quello che dichino ò stimino quelle sorte di persone di cui voi cosi poco conto [25] solete tenere. Ma questo mi potrà scusare appresso di voi che volendo io come quel che vi amo et honoro molto darvi qualche aviso del giuditio che di qua si faccia dei libri vostri, et non havendo fin quà saputo che cosa le sia stata detta in contrario da huomo di qualche momento ne le lettere ho voluto in parte raguagliarvi di quello che sia stato detto da qualche vulgare litterato. Mi resta dunque solo di confortarvi et pregarvi come fò caldamente, che vogliate seguire inanzi animosamente con questa vostra laudabile impresa et maggiormente poi che vedete che all'intelletti di giuditio sodisfa tanto; et che horamai mandiate fuora l'altre parti de la filosofia che di voi si aspettono; fo fine con questo pregandovi ancora che vi risolviate una volta à venire à viver qualche anno in questa Città come molte volte mi havete detto d'haver in animo di voler fare. Et non l'havete da desiderare senza ragione; poiche oltra le moltẹ et buone qualità sue mi havete tante volte predicate, voi in particolare ci havete un bel numero di persone che v'amano, et con desiderio v'aspettono. Vi bacio la mano et mi vi raccomando: pregando N.S. Dio che vi contenti sempre.

Di Padova el di XX d'ottobre del 51.

\section{WORKS CITED}

ALBERTINI, R. von. Firenze dalla repubblica al principato. Storiz e coscienza politica. Turin: Einaudi, 1970. 
BARGAGLI, Girolamo. Dialogo dei giouchi che nelle vegghie sanesi si usano di fare. Siena, 1572.

BELLADONNA, R. "Some Linguistic Theories of Accademia Senese and of the Accademia degli Intronati of Siena: An Essay on Continuity." Rinascimento 18 (1978): $229-48$.

BREEN, Q. "Giovanni Pico della Mirandola on the Conflict of Philosophy and Rhetoric." Journal of the History of Ideas 13 (1952).

CAPONETTO, S. Aonio Paleario (1503-1570) e la riforma protestante in Toscana. Turin, Einaudi, 1979.

CELSE, M. "Alessandro Piccolomini, l'homme du ralliement." Les écrivains et le pouvoir en Italie a l'époque de la renaissance, Voll. 2. Paris: U de la Sorbonne Nouvelle, 1973: 1 .

CERRETA, F. Alessandro Piccolomini letterato e filosofo senese del Cinquecento. Siena: Accademia Senese degli Intronati, 1960.

DE GAETANO, A. "The Florentine Academy and the Advancement of Learning through the Vernacular: The Orti Oricellari and the Sacra Accademia." Bibliotheque d'Humanisme et Renaissance 30 (1968).

DIONISOTTI, C. Geografia e storia della letteratura italiana. Turin: Einaudi, 1967.

DOUGLAS, A. The Philosophy and Psychology of Pietro Ponponazzi. Cambridge: Cambridge U P, 1910.

FAITHFULL, R.G. "The Concept of 'Living Language' in Cinquecento Vernacular Philology." The Modern Language Review 48 (1953): 278-92.

FRANCI, ADRIANO (Claudio Tolomei). Il Polito di Adriano Franci da Siena delle lettere nuovamente aggiunte nella volgar lingua, con somma diligenza corretto $e$ ristampato. Venice, 1531.

GARIN, E. Medioevo e Rinascimento. Studi e ricerche. Bari: Laterza, 1966.

. La cultura del Rinascimento. Bari: Laterza, 1967.

Giovanni Pico della Mirandola. Vita e dottrina. Florence: Le Monnier, 1937.

GREYSON, C. A Renaissance Controversy - Latin or Italian. Oxford: Clarendon Press, 1960.

. "Le lingue del Rinascimento." Il Rinascimento. Aspetti e problemi. Florence: Olschki, 1981.

HALL, R.A. Jr. The Italian "Questione della lingua." An Interpretative Essay. Chapel Hill: U of North Carolina P, 1942.

KOSUTA, L. "L'Académie Siennoise: Une académie oubliée du XVIe siècle." Bollettino senese di storia patria 87 (1980): 123-57.

. "Aonio Paleario et son groupe humaniste et reformateur à Sienne (1530-1546)." LIAS 7 (1980)

MARCHETTI, V. "Sull'origine e Ia dispersione del gruppo ereticale dei Sozzini a Siena (1557-1560)." Rivista storica italiana 81.1 (1969).

MAZZACURATI, G. La questione della lingua dal Bembo all'Accademia Fiorentina. Naples: Liguori, 1965.

PETRACCHI COSTANTINI, L. L'Accademia degli Intronati di Siena e una sua commedia. Siena: Editrice d'Arte "La Diana," 1928.

PETRONIO, G. "La crisi italiana e il rinascimento. d) Il mondo subalterno." L'attivitd letteraria in Italia. Florence: Olschki, 1981.

PICCOLOMINI, A. La prima parte dele Theoriche $\delta$ vero speculationi dei Pianeti. 
Venice: 1558.

"Al Beatissimo Padre e nostro Signore Papa Giulio Terzo." La prima parte della filosofia naturale. Rome, 1551.

. De la institutione di tutta la vita de l'huomo nato nobile, e in citta libera, libri $X$ in lingua toscana. Venice, 1542.

PIRRI, P. "Episodi della lotta contro l'eresia a Siena." Archivium historicum Societatis Iesu 30.63 (1963).

PICO DELla MIRANDOLA, G. (Gian Francesco Pico). Opera omnia [1557-1573]. Hildesheim: OIms, 1969.

ROCHON, A. "Letteratura e società nel Rinascimento italiano." Il Rinascimento. Aspetti" e problemi. Florence: Olschki, 1981.

SBARAGLI, L. Claudio Tolomei. Siena, 1939.

SCRIVANO, R. "Alessandro Piccolomini." Rassegna della letteratura italiana 68 (1964). SPERONE SPERONI. I dialoghi. Venice, 1542.

TOLOMEI, CLAUDIO. Il Cesano. Venice, 1555.

WEISS, R. "The Sienese Philologists of the Cinquecento-A Bibliographical Introduction." Italian Studies 2.1-2. 